\title{
Brush Control and Rio Grande Turkeys in North-Central Texas
}

\author{
DEE A. QUINTON, ALAN KENT MONTEI, AND JERRAN T. FLINDERS
}

\begin{abstract}
Rio Grande turkeys used brush-controlled and untreated rangeland equally when suitable roosting and other cover was available but were absent in areas having an adequate food supply with little available cover. Food selection of turkeys was based upon availability of their preferred foods at different seasons. The two most prevalent foods in each of grass, forb, mast and cactus classes were the same from both treated and untreated areas $83 \%$ of the time. Similarity indices of diets between brush-controlled versus untreated areas were $60 \%$ and $\mathbf{7 3 \%}$ for summer and fall, respectively.
\end{abstract}

The Rio Grande turkey (Meleagris gallapavo intermedia Sennett) ranges over much of Texas. In the past, turkey populations decreased to the extent of extinction on much of its former range. However, recent management practices and renewed public interest have restored turkey populations to former habitat areas and have resulted in expansion of wild turkey ranges into areas previously uninhabited by them.

The incidence of brush control is also increasing in Texas where mesquite (Prosopis spp) occurs on more than 56 million acres of rangeland; 54 million acres of this could be directly improved for forage production by some practice of brush control (Smith and Rechenthin 1964). While brush control measures undoubtedly affect turkey behaviour, the effects of such measures are not well documented. Glazener (1958) reported that clearing solid blocks of brush reduced or eliminated turkeys by reducing cover and roosting habitat. Conversely, Lehmann (1960) stated that properly applied brush control treatments can increase turkey populations.

This study was undertaken to assess the effects of brush control on turkey diets and use of habitats in north-central Texas.

\section{Study Area}

Research, extending from October 1971 to December 1972, was conducted on the Rolling Plains of north-central Texas near the juncture of Haskell, Throckmorton, and Shackelford counties. The study unit, which encompassed 12,000 ha traversed by the Clear Fork of the Brazos River, was located on parts of the Hendrick and River Ranches.

Topography ranges from level ridgetops and rugged slopes to riverbottom with $152 \mathrm{~m}$ elevation differences between ridges and the

At the time of the research, authors were assistant professor, graduate student, and assistant professor, Department of Range and Wildlife Management, Texas Tech University, Lubbock. At present Quinton is research scientist, Agriculture Canada Research Station, Kamloops, British Columbia V2B 8A9; Montei is biologist, Kansas Forestry. Fish and Game Commission, 2204 Vine, Hays, Kansas 67601; and Flinders is associate professor and director, Wildlife and Range Resources Graduate Program, Brigham Young University, Provo, Utah 84602

This report is a contribution of the College of Agricultural Sciences, Texas Tech University, Lubbock, Publication Number T-9-198.

Manuscript received September II, 1978. river. Annual precipitation varies between $51 \mathrm{~cm}$ and $76 \mathrm{~cm}$ with 69 $\mathrm{cm}$ being the average (Korschgen 1967). Temperatures range between a winter low of $-9.5^{\circ} \mathrm{C}$ to summer $45.5^{\circ} \mathrm{C}$.

The River Ranch had practiced very little brush control in recent years and was considered to represent near natural conditions for this area. This ranch provided areas of untreated riverbottom $(8 \mathrm{~km}$ long with an average width of $150 \mathrm{~m}$ ) and untreated upland (1997 ha) adjacent to the river. Riverbottom lands on the Hendrick Ranch had recently been opened by selective grubbing of mesquite ( $P$. glandulosa) and undergrowth with a crawler tractor. Upland sites had been treated with 2,4,5-T in 1964 to control mesquite. Thus, the Hendrick Ranch provided areas of treated riverbottom $(9 \mathrm{~km}$ long with an average width of $150 \mathrm{~m}$ ) and treated upland (3588 ha) adjacent to the river.

Other upland sites treated for brush control include: 228 ha grubbed with a crawler tractor to remove all brush in 1972, and 1,298 ha treated with chemical followed by chaining in 1957 and an additional chemical treatment in 1970 to control regrowth. These two areas were not adjacent to the river.

Pecan (Carya illinoensis), soapberry (Sapindus saponaria), ironwood (Bumelia lanuginosa), and tasajillo (Opuntia leptocaulis) were plentiful along the river. Walnut trees (Juglans spp) were present but infrequent in riverbottom habitat. Mesquite was the dominant tree throughout the area. Pricklypear (Opuntia spp) was abundant on all sites.

Texas wintergrass (Stipa leuchotricha), sideoats grama (Bouteloua curtipendula), purple threeawn (Aristida purpurea), sand dropseed (Sporobolus cryptandrus), and tridens (Tridens muticus) were the more abundant grasses present. Prevalent forbs included rock daisy (Melampodium leucanthum), ragweed (Ambrosia spp), firewheel (Gaillardia pulchella), annual broomweed (Xanthocephalum dracunuloides), and Arkansas dosedaisy (Aphanostephus skirrhobasis).

\section{Methods}

Diets were determined by examination of fecal material. A total of 125 fecal samples were collected from roost sites. Each sample contained an average of 25 droppings. Droppings were gathered after turkeys left their roosts in the morning. Results were combined into spring (April to July), summer (July to October) and fall (October to December) diets with each sample size containing an equal number of fecal samples.

Six different habitats, described previously, were sampled. By observing the movements of turkey flocks, their ranges were determined and feces collected at roosts which were known to be from treated or untreated areas. Samples were not collected from turkeys if their range included both ranches.

The microscopic technique of dietary analysis (Baumgartner and Martin 1939) was used to identify dietary items in fecal materials. Microscope slides were prepared as outlined by Hansen and Flinders (1969). Three slides per fecal sample and 10 fields per slide were evaluated at 100 power magnification for a total of 30 fields per individual sample.

Over 250 plant species from the study area were collected. Reference slides of all plant parts were made for verification of the 
histological features of food items identified in fecal samples. Size and shape of epidermal trichomes, presence or absence of trichomes, cell shapes and crystals included in cell walls were the histological features used to identify forb and shrub species. Grasses were identified by occurrence and position of specialized epidermal cells such as corks cells, silica cells, silica suberose crystals, and asperites (Hansen and Flinders 1969).

Food availability was measured on two $183 \mathrm{~m}$ transects randomly located in each of the six habitats sampled. Four intensive $(15 \times 8 \mathrm{~m})$ sampling units (ISU) were located at $35-\mathrm{m}$ intervals along each transect. Shrub and tree frequency, density and cover were recorded along four $2 \times 15$-m belts in each ISU. Grass and forb frequencies and cover were recorded for $30 \times 30 \mathrm{~cm}$ quadrats placed three to a line along five line transects established in each ISU. Pricklypear data were recorded as for forbs, but analyzed separately. Mast and fruit production was recorded to indicate the beginning and end of availability and relative production. Sampling was conducted during spring (May-June), summer (August), and fall (December).

An adjustment in vegetative sampling was necessary in riverbottom habitats. The first transect was placed parallel to the shoreline. The second transect was parallel to and $32 \mathrm{~m}$ distant from the first.

Data on turkey populations, their movements, and roost trees were obtained by searching the various habitats and observing turkey sign, individuals and flocks.

Insect populations were periodically sampled throughout the season by making a double pass with a sweep net along a $60-\mathrm{m}$ transect in each habitat. Turkey diets were compared for the different habitats using Kulczynski's mathematical expression of similarity (Oosting 1956).

\section{Results}

\section{Habitat Characteristics}

Vegetational differences were apparent among the six habitats and among different sampling dates on the same site. Spring and summer samples had the greatest variation (Table 1). Fall vegetation having slightly fewer forbs and more grass in the understory was not significantly different from summer vegetation thus was not included in the table.

\section{Untreated Sites}

Riverbottom habitat had the most dense brush while the other habitats were considerably more open (Table 1). Mesquite was the dominant overstory shrub, accounting for $50 \%$ of the total coverage on the riverbottom and $18 \%$ coverage on the upland sites. Tasajillo was the most prevalent shrub (75\% relative frequency) on the riverbottom, while mesquite was prevalent (41\% relative frequency) on the upland.

\section{Treated Sites}

Considering only the riverbottom and adjacent upland, mesquite accounted for about $9 \%$ of the total yearly cover along the riverbottom and $12 \%$ on the upland. Ironwood was most prevalent ( $28 \%$ relative frequency) on the riverbottom and mesquite (38\% relative frequency) interspersed with hackberry (Celtis spp) was prevalent on the upland.

Mesquite on the two upland sites not adjacent to the river (the grubbed upland and the sprayed-chained-resprayed upland) had relative frequencies of $28 \%$ and $34 \%$, respectively. Cover value of mesquite was $1 \%$ and $3 \%$ on the grubbed upland and the sprayed-chained-resprayed upland, respectively.

\section{Fruit and Insect Production}

Ironwood berries and pecan mast were plentiful in the fall of 1971. Pecan mast persisted in limited quantities through February. Ironwood berries were not available after early December, when grain sorghum (scattered by sportsmen) on the River Ranch became a staple winter food of turkeys.

In 1972 ironwood production was poor; few plants produced berries and the berries were not available to turkeys after mid-October. Pecan mast was also limited but was an important fall turkey food.

Other fruit-bearing species that appeared in turkey diets were elbowbush (Forestiera pubescens), sumacs (Rhus spp), tasajillo, and pricklypear. Elbowbush berries first appeared in early May, lasting through July. Production was heavy during the study period. Moderate amounts of fruit from polecate bush (Rhus aromatica) and littleleaf sumac (Rhus microphylla) were available in the habitats from April through July. Tasajillo fruits were available through the winter, and pricklypear fruits were available from mid-July through December.

Insect populations, sampled by sweep net, were greatest in sprayed-chained-resprayed habitats and untreated habitats. Orthoptera, Hemiptera, Homoptera, and Araneae were the most prevalent orders of insects present. Insects were abundant on the area until the first hard winter freeze.

\section{Fecal Analysis}

Seasonal data indicate that spring diets consisted of $47 \%$

Table 1. Cover and frequency of vegetation on six brush control sites in north-central Texas.

\begin{tabular}{|c|c|c|c|c|c|c|c|c|}
\hline \multirow[b]{2}{*}{ Site } & \multicolumn{4}{|c|}{$\%$ cover } & \multirow{2}{*}{$\begin{array}{c}\% \text { brush freq } \\
(2 \times 15 \mathrm{~m})\end{array}$} & \multicolumn{3}{|c|}{$\begin{array}{c}\% \text { rel. freq. } \\
(30 \times 30 \mathrm{~cm})\end{array}$} \\
\hline & Brush & Grass & Forb & Pricklypear & & Grass & Forb & Pricklypear \\
\hline \multicolumn{9}{|l|}{ May-Spring } \\
\hline Untreated upland & 21.7 & 78.9 & 18.9 & 6.1 & 59.4 & 40.3 & 48.6 & 1.7 \\
\hline Untreated riverbottom & 79.5 & 73.1 & 25.8 & 1.8 & 87.5 & 49.0 & 38.7 & 2.0 \\
\hline Grubbed riverbottom & 18.8 & 65.0 & 26.2 & 0.0 & 81.3 & 52.8 & 45.2 & 0.0 \\
\hline Sprayed upland - 1964 & 30.2 & 78.9 & 12.4 & 9.2 & 84.4 & 49.3 & 38.7 & 3.6 \\
\hline S-C-S upland ${ }^{1}$ & 3.5 & 93.8 & 4.8 & 7.9 & 56.3 & 68.6 & 28.4 & 2.3 \\
\hline Grubbed upland- 1972 & 0.0 & 54.6 & 9.0 & 0.7 & 34.4 & 45.2 & 46.5 & 4.4 \\
\hline \multicolumn{9}{|l|}{ August-Summer } \\
\hline Untreated upland & 17.8 & 92.5 & 2.6 & 3.6 & 62.5 & 64.7 & 31.4 & 3.2 \\
\hline Untreated riverbottom & 74.2 & 76.4 & 13.4 & 1.7 & 90.6 & 65.3 & 30.3 & 1.9 \\
\hline Grubbed riverbottom & 19.7 & 62.3 & 7.1 & 0.0 & 84.4 & 85.1 & 12.1 & 0.0 \\
\hline Sprayed upland -1964 & 24.8 & 86.0 & 7.3 & 5.6 & 87.5 & 63.2 & 27.8 & 4.6 \\
\hline S-C-S upland & 3.2 & 97.7 & 0.2 & 7.1 & 53.1 & 88.5 & 5.8 & 2.5 \\
\hline Grubbed upland -1972 & 0.7 & 60.2 & 10.4 & 0.9 & 37.5 & 67.9 & 23.9 & 3.5 \\
\hline
\end{tabular}

' Sprayed-chained-resprayed upland-1957 and 1972. 
insects, $37 \%$ grasses (seeds and leaves), $13 \%$ brush (seeds and fruits), $2 \%$ forbs (seeds, leaves and fruits), and $3 \%$ pricklypear tunas. Summer diets contained $31 \%$ insects, $23 \%$ brush, $23 \%$ pricklypear, $16 \%$ grasses, and $7 \%$ forbs. Fall diets included $36 \%$ brush species, $23 \%$ grasses, $15 \%$ pricklypear, $13 \%$ insects, and $12 \%$ forbs. Since observations revealed turkeys on the study area readily accepted grain sorghum spread by sportsmen, no data were collected from January through March. Thus winter feeds are not included in this paper.

Insects were important sources of food for turkeys in all habitats during spring, summer and fall (Table 2). Early ripening bristle panicum (Panicum ramisetum) and Texas cupgrass (Eriochloa sericea) seeds combined with mast from brush contributed greatly to the spring diet.

Ripened pricklypear fruits were of considerable importance as summer foods of turkeys. Turkeys switched to tridens grass seeds as bristle panicum and Texas cupgrass seeds became scarce. Brush species became more important in late summer diets as tasajillo fruits and ironwood berries ripened. Turkeys consumed available mast in fall, with pecan making up 32\% of the diet at this time. Pricklypear tunas and insects still remained important turkey foods during fall. Tridens grass seeds (20\%) and wild onions (Allium drummondii) (12\%) became valuable food sources during fall.

\section{Treated versus Untreated Areas}

Differences between turkey diets on brush control versus nontreated areas were not as great as had been anticipated. Summer diets from both categories had a similarity index of $60 \%$. Greater usage of insects and less usage of shrubs on treated areas accounted for much of the variation (Table 2). A similarity index of $73 \%$ was noted for fall diets between treated and untreated areas. As variety of food decreased in fall, pecan mast became the dominant food in turkey diets and helped account for the higher index of similarity.

Although amounts of grasses, forbs, and brush in turkey diets varied between brush-controlled and untreated areas, the two most prevalent foods in each food class from each area were the same $83 \%$ of the time. These important foods from both treated and untreated areas were: bristle panicum, tridens, wild onion, pricklypear, pecan, ironwood, and tasajillo. Turkeys were apparently demonstrating a selectivity of preferred foods throughout the range.

Availability of food items compared to occurrence in turkey diets showed that wild onion, pricklypear tunas, bristle panicum seeds, and pecan mast were preferred foods (Table 3 ). The occurrence of bristle panicum and Texas cupgrass in turkey diets from the untreated areas appeared low, but these samples were obtained during summer when many of these seeds were no longer available.

There was no evidence of turkeys frequenting the grubbed upland or sprayed-chained-resprayed areas. These sites had undergone brush control treatments aimed at total brush removal but still had ample amounts of the more important grasses, forbs, succulents, and insects frequently ingested by turkeys. In fact, of all six habitat types, insect numbers were greatest on the sprayed-chained-resprayed upland and fifth greatest on the grubbed upland. The insignificant use by turkeys of a readily available food source such as insects agrees with Glazener's (1958) observation that a relationship exists between the amount of escape cover present and turkey use of an area.

Table 2. Important species in diets of turkeys from untreated and treated brush control areas in north-central Texas.

\begin{tabular}{|c|c|c|c|c|c|c|}
\hline \multirow[b]{2}{*}{ Species $^{1}$} & \multicolumn{2}{|c|}{$\begin{array}{c}\text { Spring } \\
\text { \% rel. freq. }\end{array}$} & \multicolumn{2}{|c|}{$\begin{array}{c}\text { Summer } \\
\% \text { rel. freq. }\end{array}$} & \multicolumn{2}{|c|}{$\begin{array}{c}\text { Fall } \\
\% \text { rel. freq. }\end{array}$} \\
\hline & Untrt. & Trt. $^{2}$ & Untrt. & Trt. & Untrt. & Trt. \\
\hline \multicolumn{7}{|l|}{ Grass } \\
\hline Bristle grass seeds & 14 & & 6 & 4 & 3 & 3 \\
\hline Texas cupgrass seeds & 11 & & 2 & - & - & - \\
\hline Sorghum (grain) & 7 & & - & - & - & - \\
\hline Tridens seeds & 2 & & 11 & 5 & 11 & 23 \\
\hline Grama grasses & 2 & & - & 1 & - & - \\
\hline Squirrel-tail barley & 1 & & - & - & - & - \\
\hline Sand dropseed seeds & - & & 1 & - & - & - \\
\hline Pricklypear tunas & 3 & & 20 & 26 & 7 & 19 \\
\hline \multicolumn{7}{|l|}{ Forb } \\
\hline Silverleaf nightshade & 2 & & - & 5 & - & - \\
\hline Wild mercury seeds & - & & 1 & - & - & - \\
\hline Pelotazo leaves & - & & - & 1 & - & - \\
\hline Pigeonberry berries & - & & 1 & - & - & - \\
\hline Giant ragweed seeds & - & & - & 1 & - & - \\
\hline Wild onion leaves & - & & - & - & 19 & 9 \\
\hline \multicolumn{7}{|l|}{ Brush } \\
\hline Ironwood berries & 6 & & 9 & 4 & 3 & - \\
\hline Polecat bush berries & 6 & & 5 & - & - & - \\
\hline Mesquite & - & & 2 & 2 & - & - \\
\hline Tasajillo tunas & - & & 13 & 4 & - & - \\
\hline Pecan (mast) & - & & 1 & - & 35 & 30 \\
\hline Walnut (mast) & - & & $i$ & - & - & - \\
\hline Littleleaf sumas berries & - & & 3 & - & - & - \\
\hline Insect & 47 & & 20 & 43 & 17 & 10 \\
\hline
\end{tabular}

\footnotetext{
Those species which had a relative frequency greater than $1.0 \%$.
}

- Data not taken because roosts were not located in time. 
Table 3. Relative frequency and preference indices (PI) of most important plants found in turkey diets from treated and untreated brush control areas in north-central Texas.

\begin{tabular}{|c|c|c|c|c|c|c|}
\hline \multirow[b]{2}{*}{ Species } & \multicolumn{3}{|c|}{ Treated $^{1}$} & \multicolumn{3}{|c|}{ Untreated $^{1}$} \\
\hline & $\begin{array}{c}\% \\
\text { rel. freq. } \\
\text { in habitat }\end{array}$ & $\begin{array}{c}\% \\
\text { rel. freq. } \\
\text { in diet }\end{array}$ & $\mathrm{PI}^{3}$ & $\begin{array}{c}\% \\
\text { rel. freq. } \\
\text { in habitat }\end{array}$ & $\begin{array}{l}\% \\
\text { rel. freq. } \\
\text { in diets }\end{array}$ & PI \\
\hline Pecan & 8.5 & 30.3 & 3.6 & 8.5 & 34.6 & 4.1 \\
\hline Ironwood & 20.9 & 3.9 & 0.2 & 11.0 & 8.9 & 0.8 \\
\hline Tasajillo & 6.4 & 4.3 & 0.7 & 24.0 & 13.4 & 0.6 \\
\hline Sumac & - & - & - & - & 8.6 & - \\
\hline Pricklypear & 2.7 & 26.3 & 9.7 & 2.7 & 20.4 & 7.6 \\
\hline Wild onion & 0.7 & 8.9 & 12.7 & 1.7 & 18.5 & 10.9 \\
\hline Silverleaf nightshade & 1.1 & 5.1 & 4.6 & 1.3 & 2.5 & 1.9 \\
\hline Bristle panicum & 0.5 & 3.6 & 7.2 & 1.5 & 13.9 & 9.3 \\
\hline Texas cupgrass & 4.6 & 0.9 & 0.2 & - & 10.7 & - \\
\hline Tridens & 7.3 & 22.9 & 3.1 & 10.5 & 10.7 & 1.0 \\
\hline \multicolumn{7}{|c|}{$\begin{array}{l}\text { Riverbottom and adjacent upland habitats combined. } \\
\text { Data are those found during the period of greatest use. }\end{array}$} \\
\hline \multirow[t]{2}{*}{ Preference Index-determined by } & \multirow{2}{*}{\multicolumn{6}{|c|}{ \% relative frequency in diets }} \\
\hline & $\%$ relative $\mathrm{fr}_{\mathrm{r}}$ & abitats & & & & \\
\hline
\end{tabular}

\section{Populations and Movements}

Sightings of 119 flocks of turkeys involving 1,202 birds were recorded during 149 different observations. Most sightings occurred within $0.8 \mathrm{~km}$ of the river, all but four (nesting hens) sightings within $1.6 \mathrm{~km}$. Males and females were seldom seen commingling. Average flock size for hens with juveniles was 19 birds $( \pm 4.5 \mathrm{SD})$ from October through March and 6.8 birds ( $\pm 1.9 \mathrm{SD})$ from April through September. Conversely, toms tended to be less gregarious, averaging 4.2 birds $( \pm 3.1 \mathrm{SD})$ per flock during winter and 3.7 birds $( \pm 1.4$ $\mathrm{SD})$ per flock during summer.

A survey to determine the density of suitable roost trees over $6.1 \mathrm{~m}$ in height was taken within $30 \mathrm{~m}$ of the riverbank. Pecan was most abundant with 81 trees per $1.6 \mathrm{~km}$ of shoreline. Soapberry, hackberry, walnut, and elm (Ulnus americana) had stem counts of $49,24,2$, and 1 trees per $1.6 \mathrm{~km}$ of riverbank, respectively.

Of 68 roost trees observed, pecan was selected by turkeys 93\% of the time. Soapberry, elm, and willow (Salix nigra) served as roost $4 \%, 2 \%$ and $1 \%$ of the time, respectively. The average size of roost trees was $14.7 \mathrm{~m}$ in height with a dbh of $0.68 \mathrm{~m}$. Males preferred trees that extended over water or the upper portions of the tallest trees on land. An average of 2.2 turkeys was observed on each roost.

Rio Grande turkeys remained on the roosts longer after sunrise and returned to the roosts earlier during summer than in fall and winter. Turkeys were still on roosts 1 hour after sunrise and returned before sunset during summer. Turkeys left their roosts at sunrise and returned shortly after sunset during winter. Rio Grande turkeys in this locality thus differ from Merriams turkeys, which reportedly leave their roosts before sunrise (Hoffman 1968).

\section{Discussion}

Brush control practices do not necessarily mean a reduction in turkey populations. Good turkey populations can be maintained on properly managed brush control areas. Brush treatments on the Hendricks Ranch opened the brush cover which benefitted their cattle operation; but the treatments, which did not disturb roost and mast trees or berry producers, did not appear to reduce the turkey populations. Food and cover for turkeys could still be found in these moderate brush-controlled areas.

Areas attempting total brush removal retained several of the important food sources but cover was removed. If total brush removal is desired, then the practices should be limited to small patterned areas. This study was not designed to determine how large such cleared areas can be and still be utilized by turkeys, but cleared areas of 228 ha (grubbed upland) and 1,298 ha (sprayed-chained-resprayed upland) apparently were large enough to be avoided by turkeys.

A variety of food items was used by turkeys. Following is a discussion of a few of the more important food items in the turkeys' diets:

1) Pecan mast was the most important natural winter food. Although production was poor during the study period, mast was available through most of the winter months. Brush control measures should not interfere with this species because of its value as food and for roosting.

2) Wild onion was one of the few green forbs present during the winter months. This forb provided a large portion of the turkey's fall diet and was highly preferred. Brush control practices appeared to increase the distribution of this forb. 3) Pricklypear tunas were valuable for food during summer and fall. Maintaining some pricklypear in the habitat would benefit turkey populations.

4) Bristle panicum and Texas cupgrass were turkey favorites in the early growing season but their seeds did not persist into the fall. These grasses were not abundant in any of the habitats studied but were sought by turkeys.

5) Ironwood berries provided food for many forms of wildlife during fall. Berries did not last throughout the winter but were highly preferred when available.

6) Tridens, the most important grass species in turkey diets, retained its seeds well into the winter months and was heavily utilized from middle summer through early winter. This grass decreased following brush control.

7) Tasajillo tunas were another important source of food through winter. This plant, most abundant along the river bottom, is very troublesome to ranchers but does provide turkeys with additional winter food.

\section{Literature Cited}

Baumgartner, L.L., and A.C. Martin. 1939. Plant histology as an aid in squirrel food habitat studies. J. Wildl. Manage. 3:266-268. 
Glazener, W.C. 1958. Wildlife management as a part of range management in Texas. 11th Ann. Meet. Am. Soc. Range Manage. 10 p. (mimeo) Hansen, R.M., and J.T. Flinders. 1969. Food habits of North American hares. Range Sci. Dep. Sci. Ser. No. 1. Colorado State Univ., Ft. Collins. $17 \mathrm{p}$.

Hoffman, D.M. 1968. Roosting sites and habits of Merriam's turkeys in Colorado. J. Wildl. Manage. 32:859-866.

Korschgen, L.J. 1967. Feeding habits and foods, pp. 137-198. In O.H.
Hewitt (ed.) The Wild Turkey and Its Management. Wildl. Soc., Washington, D.C. 589 p.

Lehmann, V.W. 1960. Problems of maintaining game on range subject to brush control. Proc. 5th World For. Cong. 3:1807-1809.

Oostin, H.J. 1956. The Study of Plant Communities. W.H. Freeman and Co., San Francisco. 440 p.

Smith, H.N., and C.A. Rechenthin. 1964. Grassland restoration-the Texas brush problem. USDA Soil Cons. Serv., Temple, Texas, n.p. 